\title{
Nonprofit Board Membership and the Gender Gap
}

\section{Cathryn Cushner Edelstein}

Emerson College (USA)

According to a study conducted by BoardSource and reported in, Leading with Intent: 2017 National Index of Nonprofit Board Practices (BoardSource, 2017), 72\% of nonprofit CEO/ Executive Director positions are held by females, while only $48 \%$ are Executive Board Members and $42 \%$ are Board Chairs. The discrepancy between the number of board positions held by women versus staff leadership positions has been the subject of many recent publications. Reviewing academic and industry literature, this paper explores the relationship between an all- male board's choice of self-assessment tools and its decision-making processes related to creating a gender inclusive board. This paper provides additional insight by applying communication theoretical frameworks to analyze allmale board decision-making processes which ultimately affect recruitment outcomes.

Keywords: nonprofit board composition, nonprofit board assessment tools, nonprofit all-male boards, all-male nonprofit board recruitment, nonprofit board gender inclusivity.

$\mathrm{R}$ esearch relative to the practices and ideologies surrounding nonprofit board recruitment is necessary to better understand the results of the 2017 study conducted by BoardSource, which revealed gender inequity associated with board leadership. A thorough review of academic and nonprofit industry literature regarding decision-making among all-male board members, board self-assessment tools, and how these may inform recruitment outcomes can assist in identifying the causes. There are a multitude of processes that lead to board recruitment, and the decision-makers are often solely the board members already in place. Recognizing this, it is prudent to explore how sitting board members assess the needs of a board and how they utilize their power to recruit and appoint new members. Though literature provides detailed information that examines the processes and issues, connecting these with existing communication theoretical frameworks allows for a more comprehensive analysis of the 
14 outcomes. In this paper, four theoretical frameworks are applied to all-male group decision-making: Self-Categorization Theory, Group and Organizational Structuration Theory, Gender Schema Theory, and Groupthink Theory.

\section{NONPROFIT BOARD RECRUITMENT PRACTICES}

Nonprofit boards are often created, at least at the onset, by the founder of an organization. Cultivating a team of people with varying expertise in a field related to the cause is common practice. In addition to enthusiastic interest in the cause,

[our] research indicates that the best boards also provide professional expertise, represent the interests of their nonprofits to community leaders, recruit new talent to the organization, and provide the more rigorous management and performance oversight that funders increasingly demand (Jansen and Kilpatrick, 2004).

As tasks and committees on a board are set, people may be added to the board because of term limits or because specific knowledge, such as finance and development skills are needed. Though equally important that the charity's cause be of strong interest to all board members, a board without knowledge in these important areas must either hire an individual to do the required work or consider bringing in new people to populate the board.

The need to add board members is often because,

changes in the competitive environment can create the need for new skills in areas such as marketing (to attract new members), technology (to exploit new IT systems or the Internet), and public relations (to convey the organization's message) (Jansen and Kilpatrick, 2004).

To this end, a viable option for boards is to complete a board self-assessment and find areas where gaps in skill and leadership are evident. Once these are known, a board creates a nominating committee that is tasked to find viable candidates to interview. As such,

the nominating committee identifies candidates who will strengthen and expand the charity's mission and service (Dean, 1998: 27).

Different results may be garnered depending on the type of self-assessment tool used, the board's ability to be objective, and board dynamics.

A board often uses the outcomes of an assessment to move towards recruiting new board members. If the assessment reveals a need to bring a new individual onto a board, a decision about the kind of person needed is the next step, as 
A draft of directives the nominating committee members must follow regarding recruitment will be created and agreed upon by the board. Once a procedure for recruitment and interviewing methods have been voted on favorably, members of the nominating committee,

use relationships with current partners and friends of the organization to help recruit new board members (Bernstein and Kieltyk, 2018).

In addition, some nonprofit organizations cast a wider net by posting a board opening(s) on recruiting websites. Once a group of potential candidates is identified, the board may,

invite prospects to meet with the staff and leadership so everyone can get to know one another better and understand each other's interests and motivations (Bernstein and Kieltyka, 2018).

Care and determination throughout the process is important, as,

finding new board members is one of the most important but time-consuming tasks of not-for-profits. Not only do the candidates need to exhibit the right mix of skills and talents, but they must be deemed a fit with the board and its financial and mission-related goals for the future (Rosen, 2018).

\section{SELF-ASSESSMENT TOOLS AND NONPROFIT BOARD COMPOSITION}

There is a direct correlation between the type of self-assessment tool used and results garnered. Care in using the most effective tool is paramount. If strategic goals are identified at the start of the process,

the results of the self-assessment can be used to help evaluate where improvements are needed and refocus efforts to support the organization's mission (Johnson, 2019).

In an effort

to really make the board evaluation a valuable tool, tie it directly to the goals and strategies of the organization (Freeman, 2009: 37).

Freeman states:

Boards that take the time to develop these strategic questions have the opportunity to measure their progress toward specific plans and goals. The process of self-assessment can result in sharper, more focused board members who are prepared to shape the future of their cooperative (Freeman, 2009: 37). 
16 If a board chooses to be more gender-inclusive, the assessment used will

consider age, gender, and minority representation, as well as lay versus professional, rural versus urban, and other demographic variables to bring appropriate diversity to your board (BoardSource, 2011: 86).

\section{During this process,}

board members should be encouraged to ask questions and seek clarification before making decisions (Johnson, 2019).

An effective self-assessment should contain prompts that are qualifiable in context as the results are meant to be translated into actionable data. It is imperative that,

assessments are designed to be constructive sessions from which board members emerge with a better understanding of their own and other board members' roles and a clear set of board action plans (Renz and Herman, 2010: 265).

\section{Therefore,}

a good board assessment process provides the board with an opportunity to reflect on its contributions to the organization's success, consider how the board is functioning, pinpoint issues and identify a plan of action (Sinclair, 2017).

\section{Furthermore,}

it is critical that the board members have time to discuss all of the key issues that emerge from the assessment and to develop an action plan. The board should be able to commit a sufficient amount of time to this dialogue and the development of an action plan as a result of the assessment (Sinclair, 2017).

If a board decides that Diversity, Equity and Inclusion (DEI) is a priority, Davidson's study concluded:

Adequate assessment is merely the first step in developing a Board and an organization for DEI. Using the information gathered [in this research], a DEI strategy guide should be created to inform Boards and organizations on how to integrate what they have learned into action (Davidson, 2019: 29).

\section{As for collecting data from the assessment,}

diversity has long been oversimplified and assessments can leave Boards with a false understanding of how to prioritize DEI for their organization (Davidson, 2019: 1). 
Therefore, a section of a board self-assessment tool should include questions that refer not only to who is presently on the board in terms of identification, but contextual prompts to address a board's goals in terms of DEI.

To better understand the range of self-assessment tools available to boards and questions related to diversity, below are three examples of board self-assessment tools:

Figure 1. McKinsey and Company Nonprofit Board Self-Assessment Tool Long Form

\begin{tabular}{|c|c|c|c|c|c|}
\hline \multicolumn{6}{|c|}{ SECTION 3: ENABLERS OF BOARD EFFECTIVENESS } \\
\hline Composition & $\begin{array}{c}1 \\
\text { Poor }\end{array}$ & $\begin{array}{c}2 \\
\text { Average }\end{array}$ & $\begin{array}{c}3 \\
\text { Good }\end{array}$ & $\begin{array}{c}4 \\
\text { Distinctive }\end{array}$ & Comments \\
\hline $\begin{array}{l}\text { Understanding of } \\
\text { board } \\
\text { composition } \\
\text { needed to meet } \\
\text { organizational } \\
\text { goals }\end{array}$ & $\begin{array}{l}\text { There is little discussion of } \\
\text { desired board member } \\
\text { skills/attributes; as a result } \\
\text { board composition seems } \\
\text { to be a legacy of random } \\
\text { conversations/initiatives }\end{array}$ & $\begin{array}{l}\text { Needs discussed are } \\
\text { largely about how we can } \\
\text { get more large donors. } \\
\text { Significant gaps exist in } \\
\text { skills needed by board }\end{array}$ & $\begin{array}{l}\text { IThe process of identifying } \\
\text { board needs is not as } \\
\text { strong as it could be, but for } \\
\text { the most part few gaps } \\
\text { exist }\end{array}$ & $\begin{array}{l}\text { Systematic process for } \\
\text { identifying needed board } \\
\text { skills driven by strategic } \\
\text { plan; gaps are understood } \\
\text { and agreed to by the entire } \\
\text { board; most new board } \\
\text { members seem to "fit our } \\
\text { needs well" }\end{array}$ & \\
\hline $\begin{array}{l}\text { Process and } \\
\text { criteria for } \\
\text { recruitment }\end{array}$ & $\begin{array}{l}\text { Recruitment process is ad- } \\
\text { hoc; Board is largely } \\
\text { reactive to the suggestions } \\
\text { of a few board members/ } \\
\text { CEO }\end{array}$ & $\begin{array}{l}\text { Formal process exists to } \\
\text { identify and cultivate } \\
\text { potential members. } \\
\text { Candidate pool is generally } \\
\text { seen as more narrow and a } \\
\text { sense exists that other } \\
\text { boards in area attract a } \\
\text { stronger pool of directors }\end{array}$ & $\begin{array}{l}\text { Formal recruitment process } \\
\text { with clear criteria in place; } \\
\text { Board seems to surface a } \\
\text { strong list of potential } \\
\text { candidates, but converts on } \\
\text { a smaller percentage than it } \\
\text { would like }\end{array}$ & $\begin{array}{l}\text { Formal process with clear } \\
\text { evaluative criteria in place; } \\
\text { whole board reaches out to } \\
\text { potential members from a } \\
\text { wide range sources; } \\
\text { recruitment process is } \\
\text { continuous and with multi- } \\
\text { year horizon; new members } \\
\text { are seen as great additions } \\
\text { to the board }\end{array}$ & \\
\hline $\begin{array}{l}\text { Diversity on the } \\
\text { board }\end{array}$ & $\begin{array}{l}\text { Diversity not a topic of } \\
\text { conversation and no } \\
\text { material representation of } \\
\text { potentially useful sources } \\
\text { of diversity }\end{array}$ & $\begin{array}{l}\text { Board's view of diversity } \\
\text { not tailored to the needs of } \\
\text { the organization and board } \\
\text { has not achieved the } \\
\text { desired composition }\end{array}$ & $\begin{array}{l}\text { Board understands the } \\
\text { types of diversity needed, } \\
\text { has a plan to achieve the } \\
\text { desired diversity and is on } \\
\text { its way to fulfilling it }\end{array}$ & $\begin{array}{l}\text { Board understands types of } \\
\text { diversity needed for } \\
\text { organization and the value } \\
\text { of diversity; current } \\
\text { diversity on the board } \\
\text { adequately reflects the } \\
\text { diversity needed }\end{array}$ & \\
\hline
\end{tabular}

Source: McKinsey and Company (n.d.). "McKinsey Board Self-Assessment Tool - Long Form: Enablers of Board Effectiveness". Section 3, p. 18. Northwest Connecticut Community Foundation. <https://northwestcf.org/sites/default/files/pdf/mcKinsey\%20Board\%20Assessment\%20Tool.pdf>

This is an example of a board composition assessment that provides context for the prompt, 'Board Diversity' in the McKinsey and Company Nonprofit Board Self-Assessment Tool Long Form. The 'Diversity on the Board' section has a range of possible responses with ' 1 ' representing Poor which reads,

diversity not a topic of conversation and no material representation of potentially useful sources of diversity (McKinsey and Company, n.d.: 18).

to ' 5 ' which reads,

board understands types of diversity needed for organization and the value of diversity; current diversity on the board adequately reflects the diversity needed (McKinsey and Company, n.d.: 18).

In addition, McKinsey and Company provides the following directives in the introduction: 
This tool is meant to create an informed starting point for discussion among the leadership of a nonprofit (McKinsey and Company, n.d.: 1).

Figure 2. BoardServeNYC Board Profile Worksheet

\begin{tabular}{|c|c|c|c|c|c|c|c|c|c|c|c|c|}
\hline \multicolumn{13}{|c|}{ Current Members } \\
\hline & 1 & 2 & 3 & 4 & 5 & 6 & 7 & 8 & 9 & 10 & 11 & 12 \\
\hline \multicolumn{13}{|l|}{ Age } \\
\hline \multicolumn{13}{|l|}{ Under 18} \\
\hline \multicolumn{13}{|l|}{$19-34$} \\
\hline \multicolumn{13}{|l|}{$35-50$} \\
\hline \multicolumn{13}{|l|}{$51-65$} \\
\hline \multicolumn{13}{|l|}{ Over 65} \\
\hline \multicolumn{13}{|l|}{ Gender } \\
\hline \multicolumn{13}{|l|}{ Male } \\
\hline \multicolumn{13}{|l|}{ Female } \\
\hline \multicolumn{13}{|l|}{ Race/Ethnicity/Disability } \\
\hline \multicolumn{13}{|l|}{ African American/Black } \\
\hline \multicolumn{13}{|l|}{ Asian/Pacific Islander } \\
\hline \multicolumn{13}{|l|}{ Caucasian } \\
\hline \multicolumn{13}{|l|}{ Hispanic/Latino } \\
\hline \multicolumn{13}{|l|}{ Native American/Indian } \\
\hline \multicolumn{13}{|l|}{ Other } \\
\hline \multicolumn{13}{|l|}{ Disability } \\
\hline \multicolumn{13}{|l|}{ Resources } \\
\hline \multicolumn{13}{|c|}{ Willingness/ability to contribute financially } \\
\hline \multicolumn{13}{|c|}{ Access to Financial Resources } \\
\hline \multicolumn{13}{|c|}{ Foundation Relationships/Resources } \\
\hline \multicolumn{13}{|c|}{ Corporate Relationships/Resources } \\
\hline \multicolumn{13}{|c|}{ Government Relationships/Resources } \\
\hline \multicolumn{13}{|l|}{ Other Community Connections } \\
\hline \multirow{2}{*}{\multicolumn{13}{|c|}{ Small business }} \\
\hline & & & & & & & & & & & & \\
\hline \multicolumn{13}{|l|}{ Qualities } \\
\hline Leadership skills & & & & & & & & & & & & \\
\hline Willingness to work & & & & & & & & & & & & \\
\hline $\begin{array}{l}\text { Personal connection with the } \\
\text { organization's mission }\end{array}$ & & & & & & & & & & & & \\
\hline
\end{tabular}

Source: Davidson, M. (2009). “United Way of New York City, Board Tune-Up Kit”. BoardServeNYC. p. 7. $<$ http://tinyurl.com/uwnycboardassessmenttool>

The Board Profile Worksheet is a self-assessment tool created by Board Coach, Michael Davidson for BoardServeNYC (Davidson, 2009: 7). It provides space for board members to post the number of people that are of the gender and ethnicity stated in the 'Current Members' (Davidson, 2009: 7) section. This serves as an inventory tool by asking respondents to share the number of board members that meet the diversity descriptors. 
Figure 3. LeadingAge Mission Strategy and Stakeholders

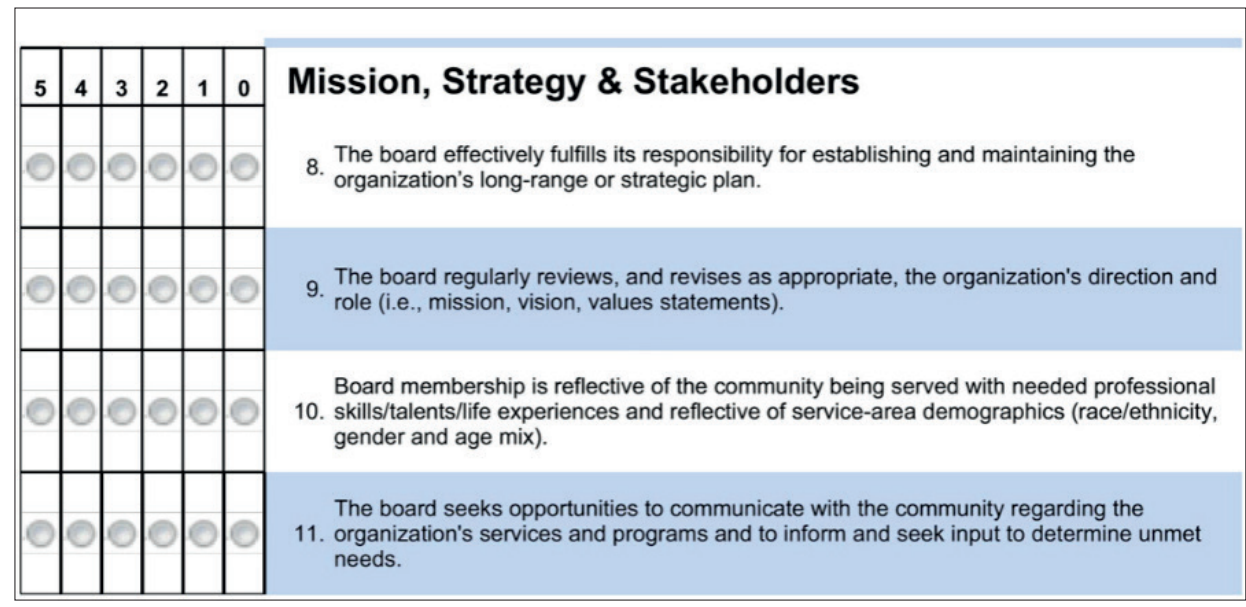

Source: LeadingAge Minnesota (2015). "Board Self-Assessment". p. 2.

<http://www.leadingagemn.org/assets/docs/Board_Assessment_Sample_Survey_LeadingAge_2017.pdf>

The Board Self-Assessment tool created by LeadingAge asks board members to rate their level of agreement on a scale of 1 to 5 for question number 10, which reads,

board membership is reflective of the community being served with needed professional skills/talent/life experiences and reflective of the service-area demographics (race/ethnicity, gender and age mix) (LeadingAge, 2015: 2).

Some boards reuse assessment tools, year after year, even if the tool used does not reveal new actionable data. This is not viewed as effective, because

by merely reprising last year's approach and using the same boilerplate questions, the self-assessment is unlikely to align with the board's annual goals and priorities and, therefore, it will not reflect the year's achievements and challenges. Nor will it raise appropriate questions about the year ahead (Schindlinger, 2018).

If the assessment tool is meant to be constructive, it follows that the tool used includes a range of questions that lead to results which will align with strategic goals.

\section{THEORETICAL ANALYSIS OF ALL-MALE GROUP DECISION- MAKING}

Theoretical frameworks can assist in understanding the decision-making process. The individuals on a board's choices are affected by gender, identity, and values, which in turn affect their decision-making behavior. The following theories will 
20 be discussed as they relate to all-male board decision-making and recruitment practices: Self-Categorization Theory, Group and Organizational Structuration Theory, Gender Schema Theory, and Groupthink.

\section{Self-Categorization Theory}

Developed by Turner, Hogg, Oakes, Reicher and Wetherell (1987), this theory is an extension of the Self-Identity Theory (SIT) which Turner developed with Henri Tajfel in 1979. It involves an extension of SIT which encompasses,

three levels of self-categorization that are important to the self-concept: the superordinate category of the self as a human being (or human identity), the intermediate level of the self as a member of a social ingroup as defined against other groups of humans (social identity), and the subordinate level of personal self-categorizations based on interpersonal comparisons (personal identity (Hornsey, 2008).

According to Turner and Reynolds,

people live, work and act in a socially structured system, where there are group-based regularities of perception, cognition and conduct and this reality has psychological consequences (Turner and Reynolds, 2012: 3).

As such,

the principle states that a collection of individuals tend to be categorized as a group to the degree inter alia that the perceived differences between them are less than the perceived differences between them and other people (outgroups) in the comparative context. As an example, in a given situation men will be categorized as independent and women as dependent when the differences between women and men in relation to this dimension are greater than those amongst the men and amongst the women available for comparison (Turner and Reynolds, 2012: 8).

In the book, Principles of Social Psychology, the authors provide a framework for social categorization,

thinking about others in terms of their group memberships is known as social categorization - the natural cognitive process by which we place individuals into social groups (Stangor, Jhangiani, and Tarry, 2014).

They further describe this as an innate process which begins when we are infants (Stangor, Jhangiani, and Tarry, 2014). It involves,

identifying people primarily on the basis of overt similarities and group membership (Dovidio, 2007: 360). 
Social identity and social categorization can prove beneficial in some circumstances, however in a managing group, such as a board, it has the potential to have a negative impact:

One problem is that social categorization distorts our perceptions such that we tend to exaggerate the differences between people from different social groups while at the same time perceiving members of groups (and particularly outgroups) as more similar to each other than they actually are (Stangor, Jhangiani, and Tarry, 2014).

Out-groups, in the case of a board comprised of all men recruiting new members could be women. When recruiting new members, strategies that were previously put in place and rendered only male recruits may be used again and perpetuate the outcome. This perpetuation of old strategies is common among working groups, as,

one difficulty with many working groups is that once they have developed a set of plans or strategies, these plans become established social norms, and it becomes very difficult for the group to later adopt new, alternative, and perhaps better, strategies (Stangor, Jhangiani, and Tarry, 2014).

\title{
Change is unlikely
}

because we tend to trust, cooperate with, and like in-group members more than outgroup members, we are attracted to, and favor in-group members and groups comprised of members similar to us (Phillips and Gully, 2013: 51).

\section{Related to recruiting women}

if men think that women are all alike, then they may also think that they all have the same positive and negative characteristics (e.g., they're nurturing, emotional) (Stangor, Jhangiani, and Tarry, 2014).

In this situation norms can be viewed as stereotypes and

the outcome is that the stereotypes become linked to the group itself in a set of mental representations (Stangor, Jhangiani, and Tarry, 2014).

\section{Group and Organizational Structuration Theory}

\author{
Conceptualized by Anthony Giddens (1986), the Group and Organizational \\ Structuration Theory involves
}

self-reported perceptions of who is connected to whom in a network and how they often differ from actual observations of who interacted with whom (Poole and McPhee, 2009: 454). 
The theory notes

the nature of structures and the relations between structure and system are represented in the concept of structuration, which refers to the process by which systems are produced and reproduced through members' use of rules and resources (Hirokawa and Poole, 1996: 117).

and

rules and resources exist only by virtue of being used in practice (Poole and McPhee, 2009: 454).

Therefore, rules can be legitimized within a group by being created and followed. In relation to how an all-male board may vote on recruitment methods and finally on whom it selects to become a board member,

by voting, the group is producing and reproducing the rules for present and future use (Poole and McPhee, 2009: 454).

It is seen as challenging, but not impossible to change rules that have been voted on and perpetuated, but given that

effective power moves often reproduce the orders of domination that they depend on (Hirokawa and Poole, 1996: 123).

it is unlikely without strategic intention, processes for recruiting and selecting board members will change.

\section{Gender Schema Theory}

The Gender Schema Theory developed by Sandra Bem (1981) involves how an individual at an early age identifies regarding gender. Zukauskas noted:

This framework informs the individual's behavior and allows him or her to categorize new information and situations as being consistent or inconsistent with what they already understand about sex and gender roles (Zukauskas, 2019).

How one identifies per this theory, influences an individual's belief about gender attributes, both positive and negative. Regarding an all-male board's decision whether to consider recruiting women,

it follows that institutional forces shaping gender schema will affect the level of female representation on corporate boards within a given institutional context (Lewellyn and Muller-Kahle, 2019).

In a study conducted by Lewellyn and Muller-Kahle (2019), 
the findings stress the importance of recognizing how the institutional context that cor-

porate boards are embedded in influences schemas about the appropriateness of women serving in positions of power (Lewellyn and Muller-Kahle, 2019).

From a social structural perspective,

this is because men are attributed higher status and privilege, and they are more likely to be in leadership roles that are congruent with their sociodemographic gender. In contrast, women are perceived as having lower status and less privilege, and the leadership role is seen as being incongruent with their sociodemographic gender (Ayman and Korabik, 2010: 159).

Attributed to Myra Ferree (1990), Ayman and Korabik write:

Thus, gender is both a hierarchical structure of opportunity and oppression as well as an affective structure of identity and cohesion (Ayman and Korabik, 2010: 158).

\section{Groupthink THEORY}

Janis' Groupthink Theory (1972) describes intragroup decision-making and the negative effects that are realized when a group concurs that it is correct without the consideration of outside perspectives. In other words,

groupthink is the extreme concurrence-seeking displayed by decision-making groups that is predicted to result in highly defective decisions (Levine and Hogg, 2010: 390).

In his own words,

Janis, [however] defined it a little more broadly, as, "a quick and easy way to refer to a mode of thinking that people engage in when they are deeply involved in a cohesive in-group, when the members" strivings for unanimity override their motivation to realistically appraise alternative courses of action (Kretchmar, 2019: 9).

Without considering outside perspectives, a group that makes decisions with its own determinants guiding the decision will rationalize the outcome. The probability of this occurrence is increased because

most charitable nonprofits have self-perpetuating boards. New members of a self-perpetuating board are selected by the existing members of the board, who identify and enlist individuals according to criteria established by the board itself (Worth, 2009: 84).

Without being challenged internally during the process of decision-making,

groupthink causes groups to believe that their goals are based on ethical principles and to stop questioning the morality of their behaviour which in turn leads to over-optimism (Kamalnath, 2017: 95). 
The group will consider itself successful as

each member believes that if the leader and each member of the group decides that it is okay, then the plan is bound to succeed (Kamalnath, 2017: 99).

\section{It is important to realize that Groupthink is not intentional and nonprofit boards are not immune to it as}

groupthink occurs at all social levels and across all sectors and industries. It happens when the entirely normal human pursuit of social harmony has the effect of stifling alternative viewpoints and suppressing dissent. It takes place when leadership teams are formed of people with overly similar backgrounds, and when members isolate themselves from outside influences and uncomfortable or challenging opinions (Gallop, 2018).

\section{Furthermore,}

symptoms of group-think consist of the illusion of invulnerability (the group can do no wrong), collective rationalization, stereotypes of outgroups, self-censorship (individuals do not express any objections to the group decision), mindguards (group members who enforce conformity), and belief in the inherent morality of the group (Levine and Hogg, 2010: 390).

Though

other options might be more beneficial [but] they choose to be united to avoid conflicts or due to group pressure (Businesstopia, 2018).

\section{This brings to light the concept of self-censorship which}

pertains to a situation where members are hesitant to voice dissenting views because of their desire to concur with the group. Thus, they would rather self-censor and remain silent or publicly agree, than raise their concerns and be treated as outcasts in the group (Kamalnath, 2017: 100).

Per Janis,

while this is not always bad, too much cohesiveness may be detrimental for decision-making because members of the group tend to avoid conflict to reach a consensus quickly (Kamalnath, 2017: 96).

The notion of avoiding conflict and agreeing with the terms set by a board leaves an individual board member with dissenting views little opportunity to voice their concerns. Ultimately, a board will move forward with its group decision, and if

existing members of the board do not recognize the importance of diversity, they may continue to select new members who are just like them, drawing on their own business and social circles to fill board openings (Worth, 2009: 84). 


\section{ADDRESSING GENDER EQUITY WITH ALL-MALE NONPROFIT BOARDS}

It is suggested that board members accept the input of others, outside the boardroom and

take advantage of all of their social capital, and consider holding conversations among male colleagues to discuss what they can do to address inequity issues (Nonprofit HR, 2018).

\section{It is advised that}

a board, consider forming an advisory council of stakeholders from the community such as clients they work closely with, major donors and occasional givers, previous board members, or other nonprofits familiar with their cause, and ask these individuals what they think a good board looks like (Ward and Miller-Stevens, 2013: 54).

This is especially advisable for larger organizations, where only 33\% of board members are women in organizations with incomes of over \$25 million or more (Shankie, 2015). It has been found that

size and scope of the organization tend to be good predictors of the presence of females on the boards - smaller, less prestigious nonprofit organizations tend to have more women on their boards (Ward and Miller-Stevens, 2013: 14).

Shankie adds:

This dynamic has long been acknowledged: The richer the organization, the less gender diversified its leadership (Shankie, 2015).

\section{Diversity and inclusion training could}

facilitate this process [by] eradicating the masculine stereotypical image of a leader, eliminating the ethnocentrism that creates ingroup-outgroup biases, and equalizing access to power and privilege (Ayman and Korabik, 2010: 167).

This may help an all-male board understand

a board that has greater gender diversity has more effective governance practices and is more likely to have policies and practices related to diversity (Buse, Bernstein, and Bilimoria, 2014: 19).

\section{Kathleen Buse, Ruth Sessler Bernstein, and Diana Bilimoria's study found}

that gender diversity on nonprofit boards not only impacts board internal and external governance practices but also impacts the policies and practices of the board related to diversity and inclusion (Buse, Bernstein, and Bilimoria, 2014: 19). 
26 Gender diverse boards reinforce DEI practices. This is important as

boards that become too insular, either by electing the same people to leadership positions or by selecting new members in their same mold, can easily miss opportunities to strengthen the organization by introducing fresh perspectives and diverse voices (BoardSource, 2011: 98).

\section{GENERATIVE THINKING AND DECISION-MAKING}

Literature regarding productive decision-making includes the concept of generative thinking. William Ryan offers this definition:

Generative thinking is a cognitive process for deciding what to pay attention to, what it means, and what to do about it (Ryan, 2007).

This is a more holistic tact as

the board "decides what to decide"; discerns challenges and opportunities; and probes assumptions, logic and the values behind strategies (Ryan, 2007).

A benefit described by Dean (2015) is:

Generative thinking tackles habits of thinking that hold us back from making good strategic decisions (Dean, 2015).

Additionally,

generative thinking explores and challenges norms to ensure that change is welcomed when needed (Davidson, 2019: 7).

This is a shift from more common styles of discussion and decision-making as

in generative thinking, Boards often discuss why and how they operate and if that serves the organization in the most effective ways (Davidson, $2019: 7$ ).

Applied to assessment outcomes,

generative thinking provides a sense of what knowledge, information, and data mean (Chait, Ryan, and Taylor, 2005: 84).

Ryan offers this advice for moving boards towards what he calls a "generative mode"

during discussions about even seemingly routine matters, look for generative landmarks. These include multiple interpretations by board members about what a situation is or 
what requires attention, or indications that an issue means a great deal to many of the board members and touches on their perception of the organization's core values (Ryan, 2007).

The reality is

although generative work is essential to governing, boards do very little of it (Chait, Ryan, and Taylor, 2005: 89).

\section{CONCLUSION}

Increasing female representation on nonprofit boards is a complex process. Literature supports the notion that change begins with recognition of this need by board members, as they are the catalysts for change and control the recruitment process. Interrupting the cycle of all-male boards continuing to recruit and appoint males may be challenging, however if increasing diversity on a board is recognized as beneficial and becomes a strategic goal, change is inevitable. As revealed in this paper, this may necessitate changing the dynamics of all-male group decision-making along with acknowledging the benefits of diversifying a board's membership. Self-assessment tools could then be selected that align with achieving this strategic goal. Eliminating the gender gap per the literature reviewed would improve a board's management capacity by incorporating diverse thoughts and voices into the leadership. The fifth United Nations Sustainable Development goal to "Ensure women's full and effective participation and equal opportunities for leadership at all levels of decision making in political, economic and public life" (UN, 2015) recognizes the need for women to be in leadership positions. Towards this goal, nonprofit organizations have a responsibility to address gender inequity on boards and confront the challenges that continue to produce all-male boards.

Future contributions in this area of scholarship could explore how nonprofit organizations and the public are responding to issues surrounding board representation, as a change in public access to the diversity of nonprofit organizational leadership is on the horizon. Guidestar is currently underway in its three year plan to collect and share data reported by nonprofits, stating:

We are well positioned to gather and organize demographic data from nonprofit organizations and to make this data available to inform discussions, decision making, and action around the issues of diversity, equity, and inclusion (DEI) in the social sector (Guidestar, 2019).

Guidestar encourages organizations to voluntarily provide DEI data with the prompt:

Many funders have requested that we collect demographic information from organizational leaders (Guidestar, 2020). 
28 The biggest motivator for organizations to voluntarily share this information may be money, as nonprofits compete for funding. With more than half of all nonprofit organizations reporting all-male boards (BoardSource, 2017) and seventy-one percent of Executive Board Chairs reporting satisfaction with current board diversity representation (BoardSource, 2017), it will be interesting to see if 'gender exclusive' boards ultimately share this data with Guidestar. If not, future research investigating the ramifications of maintaining status quo and its effect on financial solvency will be valuable.

Cathryn Cushner Edelstein (cathryn_edelstein@emerson.edu), BS (Boston University), MA (New York University), Senior Executive-in-Residence, is the creator and director of the Nonprofit Communication Management Program at Emerson College, teaching both Introduction to Nonprofit Communication Management and Nonprofit Fundraising Campaigns. The Nonprofit Program provides experiential collaboration between students and nonprofit organizations. Students plan, create, and execute successful campaigns for nonprofit organizations and local public schools, and perform social media audits for nonprofit organizations. Additionally, Professor Edelstein teaches Intercultural Communication and is the faculty director of the Paris Global Pathways Program.

\section{References}

Alexander, Lisa (2017). "Why Women are Still Underrepresented in Nonprofit Leadership and What We Can Do About It". Nonprofit HR. Available at: <https://www. nonprofithr.com/women-underrepresentednonprofit-leadership $>$. Accessed 10 September 2019.

Ayman, Roya and Korabik, Karen (2010). "Leadership: Why Gender and Culture Matter". American Psychologist, 65(3), pp. 157-170. APA PsycNet Journal. Available at: <https:// psycnet.apa.org/doi/10.1037/a0018806>. Accessed 15 August 2019.

Bernstein, Andrew and Kieltyka, Hailey (2018). Orr Associates, Inc. (OAI). "Rules of (Board) Engagement: How to Recruit the Right Board Members for Your Nonprofit. Guidestar Blog". Availableat:<https://trust.guidestar.org/ rules-of-board-engagement-how-to-recruit- the-right-board-members-for-your-nonprofit>. Accessed 26 August 2019.

BoardSource (2010). The Handbook of Nonprofit Governance. Hoboken: John Wiley \& Sons.

-. (2011). The Nonprofit Board Answer Book: A Practical Guide for Board Members and Chief Executives. John Wiley \& Sons, Inc.

-. (2017). Leading with Intent: 2017 National Index of Nonprofit Board Practices. Available at: <https://leadingwithintent.org/wp-content /uploads/2017/09/LWI2017.pdf>. Accessed 26 August 2019.

-. (2019). BoardSource Board Self-Assessment FAQs. Available at: <https://boardsource. org/board-self-assessment-faqs/>. Accessed 15 August 2019.

Bowen, Gary and Pittman, Joe F. (eds.) (1995). "The Work and Family Interface: 
Toward a Contextual Effects Perspective". Minneapolis, MN: National Council on Family Relations. Semantic Scholar, pp. 122-137. Available at: <https://www.semanticscholar.org/ paper/The-Work-and-Family-Interface\%3AToward-a-Contextual-Bowen-Pittman/f8272a e69bc75cec10e217e58e2c6022a9c278d0\#citi ng-papers $>$. Accessed 15 August 2019.

Buse, Kathleen; Bernstein, Ruth S., and Bilimoria, Diana (2014). "The Influence of Board Diversity, Board Diversity Policies and Practices, and Board Inclusion Behaviors on Nonprofit Governance Practices". SIAS Faculty Publications. Available at: <https://digitalcommons.tacoma.uw.edu/ias_pub/644>. Accessed 26 August 2019.

Businesstopia (2018). "Groupthink Theory". Available at: <https://www.business topia.net/mass-communication/groupthinktheory>. Accessed 26 August 2019.

Chait, Richard P.; Ryan, William P., and Taylor, Barbara E. (2005). Governance As Leadership: Reframing the Work of Nonprofit Boards. Hoboken, NJ: John Wiley \& Sons, Inc.

Davidson, Alexa (2019). Developing a Nonprofit Board for Diversity, Equity, and Inclusion: An Effective Tool for Measuring a Boards Vulnerabilities, Readiness, and Integrity. University of San Francisco Scholarship Repository. Masters Projects and Capstones. Available at: <https:// repository.usfca.edu/capstone/895/>. Accessed 15 August 2019.

Davidson, Michael (2009). "United Way of New York City, Board Tune-Up Kit". BoardServeNYC, p. 7. Available at: <https://www. uwnyc.com/boardservenyc/?pg=site\&area= publicdownload\&libdoc=Nonprofit $\% 5$ FTune Up\%5FKit\%2Epdf > . Accessed 28 May 2020

Dean, James C. (1998). "The Nominating Committee". Fundraising Management, vol. 28 (12), pp. 27-31. Europe PMC. Available at: <https://europepmc.org/article/ med/10179031>. Accessed 8 August 2019.

Dean, Peter (2015). "Generative Thinking to Improve Strategy". Wharton Magazine. Available at: <https://whartonmagazine. com/blogs/power-of-generative-thinking-toimprove-company-strategy $>$. Accessed 8 August 2019.

DiMento, Maria (2014). "Lack of Women in Top Roles Hinders Nonprofits, Female Nonprofit Workers Say". The Chronicle of Philanthropy News and Analysis. Available at: <https://www.philanthropy.com/article/Lackof-Women-in-Top-Roles/153197>. Accessed 8 August 2019.

Dovidio, John F. and Roselberg, Steven G. (ed.) (2007). "Intergroup Relations". Encyclopedia of Industrial and Organizational Psychology. Vol. 1, pp. 359-362. Thousand Oaks, CA. Sage. Available at: <http://dx.doi.org/10.4135/9781412952651. n139>. Accessed 6 August 2019.

Ferree, Myra M. (1990). “Beyond Separate Spheres: Feminism and Family Research". Journal of Marriage and the Family, Minneapolis, vol. 52, issue 4, 866. Available at: <https://www. jstor.org/stable/353307?seq=1 $>$. Accessed 6 August 2019.

Freeman, Jean (2009). "A Look in the Boardroom Mirror". Rural Cooperatives Magazine, vol. 76, no. 2, pp. 25-38. Available at: <https://www.questia.com/magazine/1G1199069336/a-look-in-the-boardroom-mirror>. Accessed 6 August 2019.

Gallop, Nick (2018). "Don't Let Your Team Become a Silent Circle of Assent". The Times Educational Supplement. Available at: <https:// www.tes.com/magazine/article/dont-let-yourteam-become-silent-circle-assent>. Accessed 15 August 2019.

Giddens, Anthony (1986). The Constitution of Society: Outline of the Theory of Structuration. University of California Press.

Guidestar (2019). "Diversity, Equity, and Inclusion. Building the Infrastructure for Diversity, Equity, and Inclusion (DEI) for the Nonprofit Sector". Available at: <https://www. dropbox.com/s/dnftionzfjtdavz/GuideStar. DEI.Data3YearPlan2018.pdf?dl=0>. Accessed 6 August 2019.

-. (2020). "How to Complete the Demographics Section of your Nonprofit Profi- 
le". Available at: <http://help.guidestar.org/ en/articles/3156343-how-to-complete-thedemographics-section-of-your-nonprofitprofile>. Accessed 24 May 2020.

Hirokawa, Randy and Poole, Marshall Scott (eds.) (1996). "Communication and Group Decision Making". Thousand Oaks, CA; London: Sage Publications. Available at: <http:// sk.sagepub.com/books/communication-andgroup-decision-making-2e>. Accessed $15 \mathrm{Au}$ gust 2019.

Hornsey, Matthew (2008). "Social Identity Theory and Self-Categorization Theory: A Historical Review". Social and Personality Psychology Compass 2/1, pp. 204-222. Available at: <https://doi.org/10.1111 /j.1751-9004.2007.00066.x>. Accessed $15 \mathrm{Au}-$ gust 2019.

Janis, Irving L. (1991). "Victims of Groupthink". Political Psychology, vol. 12, no. 2, pp. 247-278. Available at: <https://www. jstor.org/stable/3791464>. Accessed 6 August 2019.

Jansen, Paul J. and Kilpatrick, Andrea R. (2004). "The Dynamic Nonprofit Board". McKinsey Quarterly. Available at: <https:// www.mckinsey.com/industries/social-sector/ our-insights/the-dynamic-nonprofit-board>. Accessed 15 August 2019.

Johnson, Patricia A. (2019). "A Refresher on Not-for-Profit Board Governance: Certified Public Accountant". The CPA Journal, vol. 89, no. 4. pp. 16-17. Available at: <https://www. cpajournal.com/2019/05/03/a-refresher-onnot-for-profit-board-governance $>$. Accessed 26 August 2019.

Kamalnath, Akshaya (2017). "Gender Diversity as the Antidote to 'Groupthink' on Corporate Boards”. Deakin Law Review, vol. 22, pp. 85-106. Available at: <https://ojs.deakin. edu.au/index.php/dlr/article/view/723/668>. Accessed 15 August 2019.

Kretchmar, Jennifer (2019). "Groupthink". Salem Press Encyclopedia.

Lapin, Avrum (2018). "Skin in the Game: The Importance of Board Giving. Giving
USA". Available at: <https://givingusa.org/ skin-in-the-game-the-importance-of-boardgiving $>$. Accessed 26 August 2019.

LeadingAge Minnesota (2015). "Board Self-Assessment", p. 2. Available at: <https:// www.leadingagemn.org/assets/docs/Board_ Assessment_Sample_Survey_Leading Age_2017.pdf>. Accessed 25 May 2020.

Levine, John M. and Hogg, Michael A. (eds.) (2010). "Groupthink". Encyclopedia of Group Processes \& Intergroup Relations. Vol. 1. Thousand Oaks, CA: Sage Reference, pp. 390-393.

Lewellyn, Krista B. and Muller-Kahle, Maureen (2019). "The Corporate Board Glass Ceiling: The Role of Empowerment and Culture in Shaping Board Gender Diversity". Journal of Business Ethics, pp. 1-18. Available at: <https://doi.org/10.1007/s10551-019-041169>. Accessed 15 August 2019.

Masaoka, Jan (2008). "Boards of All-Volunteer Organizations". A Magazine of the Nonprofits Insurance Alliance. Available at: $<$ https://blueavocado.org/board-of-directors/ boards-of-all-volunteer-organizations $>$. Accessed 15 August 2019.

-. (2011). "The Nonprofit's Guide to Human Resources: Managing Your Employees \& Volunteers". Berkeley, CA: Nolo.

McCambridge, Ruth (2014). "GuideStar Will Collect Diversity Data "At Scale" with Nonprofit Sector". Nonprofit Quarterly. Available at: <https://nonprofitquarterly.org/guidestarwill-collect-diversity-data-at-scale-with-nonprofit-sector>. Accessed 15 August 2019.

-. (2018). “Nonprofits' Gender Gap Persists, Says GuideStar, and the Largest May Get Worse". Nonprofit Quarterly. Available at: <https:// nonprofitquarterly.org/nonprofits-gendergap-persists-says-guidestar-and-the-largestmay-get-worse>. Accessed 15 August 2019.

McKeever, Brice S. (2018). "The Nonprofit Sector in Brief 2018". Urban Institute, National Center for Charitable Statistics. Available at: <https://nccs.urban.org/publication/ nonprofit-sector-brief-2018>. Accessed $26 \mathrm{Au}$ gust 2019. 
McKinsey and Company (n.d.). "McKinsey Board Self-Assessment Tool - Long Form: Enablers of Board Effectiveness". Section 3, p. 18. Northwest Connecticut Community Foundation. Available at: <https://northwestcf. org/sites/default/files/pdf/McKinsey\%20 Board\%20Assessment\%20Tool.pdf $>$. Accessed 29 May 2020.

Nonprofit HR (2018). "Nonprofit Leaders Discuss Pay, Power, Privilege: Gender Equity in the Social Sector". Available at: <https:// www.nonprofithr.com/gender-equity-eventrecap $>$. Accessed 8 August 2019.

Phillips, Jean and Gully, Stanley (2013). Organizational Behavior: Tools for Success. 2nd ed. Mason, $\mathrm{OH}$ : South-Western Cengage Learning.

Poole, Marshall Scott and McPhee, Robert D. (2009). "Group and Organizational Structuration Theory". Encyclopedia of Communication Theory, vol. 1, Sage Reference, pp. 450-455.

Randel, Amy E. (2002). "Identity Salience: A Moderator of the Relationship Between Group Gender Composition and Work Group Conflict". Journal of Organizational Behavior, 23(6), pp. 749-766. Available at: <www.jstor. org/stable/4093652>. Accessed 15 August 2019.

Renz, David and Herman, Robert D. (eds.) (2010). The Jossey-Bass Handbook of Nonprofit Leadership and Management. 3rd ed. San Francisco, CA: Jossey-Bass.

Rosen, Julie A. (2018). "Finding the Right Nonprofit Board Members? Formulate a Plan". Witt/Kieffer. Guidestar. Available at: $<$ https://trust.guidestar.org/finding-the-rightnonprofit-board-members-formulate-a-plan>. Accessed 15 August 2019.

Ryan, William (Presenter). (2007). "Governance as Leadership: Reframing the Work of the Nonprofit Board". The Pew Charitable Trusts' Information Series; Programs Adjusting to a Changing Environment (PACE). Available at: <https://www.pewtrusts.org/ /media/ legacy/uploadedfiles/wwwpewtrustsorg/ reports/pew_fund_for_hhs_in_phila /governance20as20leadership20summary 20finalpdf.pdf $>$. Accessed 26 August 2019.

Schindlinger, Dottie (2018). "Doing Board Self-Assessments That Actually Matter". American Hospital Association. AHA Trustee Services. Available at: <https://trustees.aha.org/ sites/default/files/trustees/Board\%20SelfAssessment\%202018.pdf $>$. Accessed 8 August 2019.

Shankie, Erin (2015). "Women in PowerOr, Not So Much: Gender in the Nonprofit Sector". Nonprofit Quarterly. Available at: <https:// nonprofitquarterly.org/women-in-poweror-not-so-much-gender-in-the-nonprofitsector>. Accessed 26 August 2019.

Sinclair, Cynder (2017). "How to Conduct an Effective Board Assessment for Your Nonprofit". Available at: <https://www. nonprofitkinect.org/article/10689-howto-conduct-an-effective-board-assessmentfor-your-nonprofit>. Accessed 8 August 2019.

Stangor, Charles; Jhangiani, Rajiv, and Tarry, Hammond (2014). "Principles of Social Psychology - First International Edition". BC campus Open Ed, Minneapolis. Open Textbook Library. Chapter 11 Stereotypes. Prejudice, and Discrimination. Available at: <https:// opentextbc.ca/socialpsychology>. Accessed 26 August 2019.

Tajfel, Henri and Turner, John. C. (1979). "An Integrative Theory of Intergroup Conflict". In: Austin, W. G. and Worchel, S. (eds.). The Social Psychology of Intergroup Relations. Monterey, CA: Brooks/Cole, pp. 33-47.

The NonProfit Times (2018). "Nonprofit Boards Don't Resemble the Rest America". Available at: $<$ https://www.thenonprofittimes. com/npt_articles/nonprofit-boards-dontresemble-rest-america>. Accessed 26 August 2019.

Turner, John C.; Hogg, Michael A.; Oakes, Penelope J.; Reicher, Stephen D., and Wetherell, Margaret S. (1987). Rediscovering the Social Group: A Self-Categorization Theory. Oxford, UK: Blackwell. 
Turner, John C. and Reynolds, Katherine J. (2012). Self-Categorization Theory. Handbook of Theories of Social Psychology. Vol. 2, pp. 399417. London. Sage Publications Ltd.

United Nations (UN) (2016). "Sustainable Development Goals". New York. UN. Accessed at: <https://www.un.org/sustainabledeve lopment/gender-equality>. Accessed $26 \mathrm{Au}-$ gust 2019.

Ward, Kevin D. and Miller-Stevens, Katrina (2013). "Motivated to Serve: A Public
Service Motivation Perspective on Nonprofit Board Membership". Presented to the Georgia Center for Nonprofits. Available at: <https:// js.sagamorepub.com/jnel/article/view/5938>. Accessed 13 August 2019.

Worth, Michael J. (2009). Nonprofit Management Principles and Practice. Thousand Oaks, CA: Sage Publications.

Zukauskas, Rebecca (2019). "Gender Schema Theory". Salem Press Encyclopedia. 